\title{
Communication
}

\section{Enzyme-Catalyzed Transetherification of Alkoxysilanes}

\author{
Vincenzo Abbate ${ }^{1, \dagger}, *$ Kurt F. Brandstadt ${ }^{2}$, Peter G. Taylor ${ }^{1}$ and Alan R. Bassindale ${ }^{1, *}$ \\ 1 Department of Chemistry and Analytical Sciences, The Open University, Walton Hall, Milton \\ Keynes MK7 6AA, UK; E-Mail: p.g.taylor@open.ac.uk \\ 2 Dow Corning Corporation, 2200 W Salzburg Rd, Midland, MI 48686, USA; \\ E-Mail: k.f.brandstadt@dowcorning.com
}

$\dagger$ Present address: Institute of Pharmaceutical Science, King’s College London, 150 Stamford Street, London SE1 9NH, UK.

* Authors to whom correspondence should be addressed;

E-Mails: vincenzo.abbate@kcl.ac.uk (V.A.); a.bassindale@open.ac.uk (A.R.B.);

Tel.: +44-207-8484501 (V.A.); +44-1908-653363 (A.R.B.); Fax: +44-1908-858327 (A.R.B.).

Received: 27 November 2012; in revised form: 20 December 2012 / Accepted: 8 January 2013 / Published: 18 January 2013

\begin{abstract}
We report the first evidence of an enzyme-catalyzed transetherification of model alkoxysilanes. During an extensive enzymatic screening in the search for new biocatalysts for silicon-oxygen bond formation, we found that certain enzymes promoted the transetherification of alkoxysilanes when tert-butanol or 1-octanol were used as the reaction solvents.
\end{abstract}

Keywords: enzyme; biomimetic catalysis; transetherification; alkoxysilane

\section{Introduction}

Biotransformations are chemical processes which occur under the influence of biological materials such as peptides and proteins. Amongst the myriad examples of bio-mediated transformations we have focused our attention on enzyme-catalyzed reactions at a silicon centre.

In the literature, there are several examples of organo-silicon biotransformations, such as the selective synthesis of organosilicon esters under mild reaction conditions [1], enzymatic silicone oligomerization catalyzed by a lipid-coated lipase [2], and the hydrolysis of silatranes catalyzed by 
an esterase obtained from the yeast Rhodotorula mucilaginosa [3]. In addition, nature provides many examples of reactions from simple to very complex with Si-substrates, where peptides and proteins are generally considered to be the undisputed arbiters [4,5]. Examples include silica formation in diatoms and other silica-forming organisms $[4,5]$.

Our group has extensively studied silica precipitation [6] and the enzyme-catalyzed hydrolysis and condensation of alxokysilanes [7-9] under mild conditions. We have discovered several enzymatic candidates which were able to perform such reactions at room temperature and neutral $\mathrm{pH}$ and have investigated the potential involvement of their respective active sites in the biocatalyzed organo-silicon transformations.

In this work, we report a new enzyme-mediated reaction, namely the transetherification of alkoxysilanes, under mild conditions. Normally, the transetherification of alkoxysilanes requires extreme reaction conditions, including high temperatures, and the use of toxic chemicals. The use of mild (bio)-catalysts would therefore open a new way of performing such useful transformations, which is the subject of the present contribution.

\section{Results and Discussion}

During our previous work on enzyme-catalyzed organo-silicon transformations, we were interested in siloxane-bond formation in the presence of biocatalysts both in aqueous and aqueous-organic media. Several monophasic and biphasic aqueous-organic systems were investigated as reaction solvents. One of the biphasic-aqueous organic systems employed during the alkoxysilane studies consisted of 1-octanol saturated with tris-buffered water. In addition to the previously observed enzyme-catalyzed hydrolysis and condensation of alkoxysilanes [9], the formation of the octylsilyl ethers as a result of transetherification and/or silanol-alcohol condensation/exchange was also detected in this solvent whereas no equivalent reaction was seen in the negative control reactions (Scheme 1). The "side-product" octyl-silyl ether was identified as a new peak which appeared in the gas-chromatogram following reaction and work-up when compared to our standard set of peaks which arise from solvents (THF, ethanol and 1-octanol), unreacted starting material, hydrolyzed silanol, and the disiloxane condensation product.

Scheme 1. Enzyme-catalyzed transetherification and/or silanol-alcohol condensation.

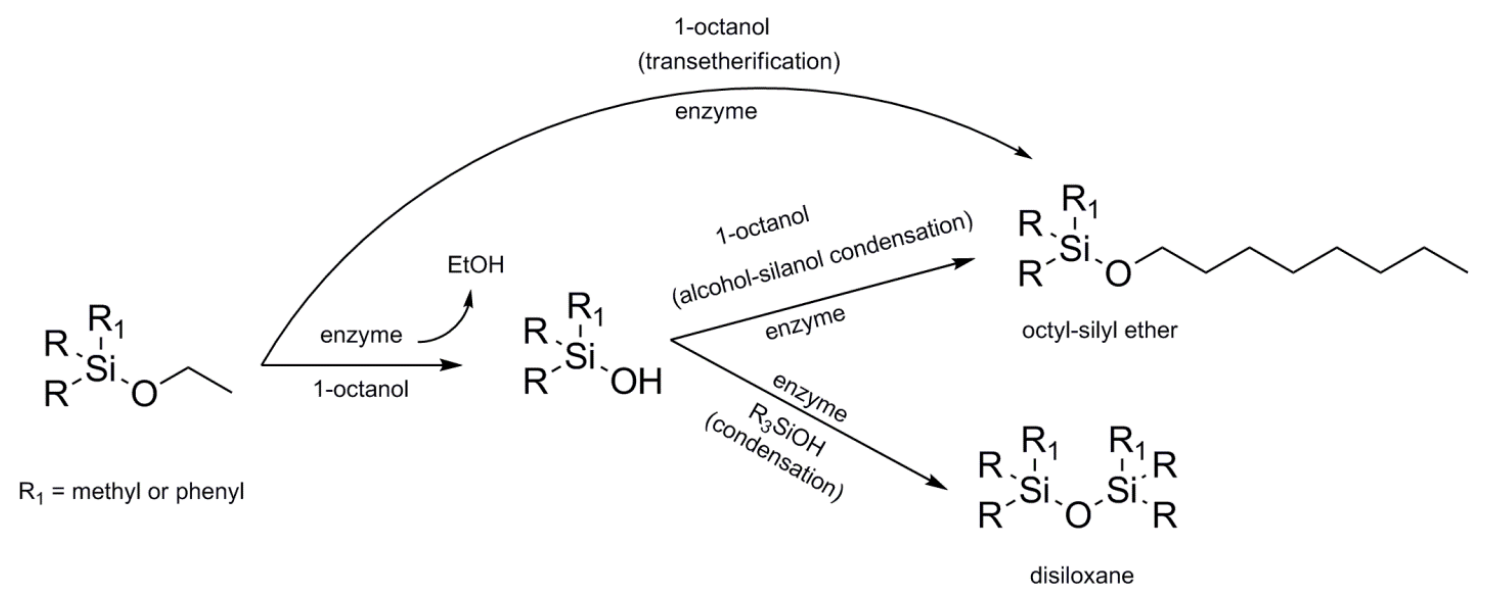


The identity of the structure was further investigated by means of GC-MS (not shown) and was confirmed to be the alkoxyoctylsilyl ether.

The reactions were formulated with approximately 5:1 alkoxysilane to enzyme weight ratio in wet (water-saturated) 1-octanol (5:1 solvent to alkoxysilane weight ratio) and conducted in inert glass vials. After $24 \mathrm{~h}$ of stirring at room temperature, the reactions were filtered and quantitatively analyzed by GC-FID. The gas chromatography analysis was performed with an Agilent 6890 Series injector on an Agilent 6890 plus gas chromatograph with a flame ionization detector.

Dodecane was used as an internal standard to quantitate the chromatographic analyses. The samples were prepared at $\sim 1 \%(\mathrm{w} / \mathrm{w})$ product in a THF solution containing $1 \%(\mathrm{w} / \mathrm{w})$ dodecane.

In order to chromatographically quantify the trimethyloctyloxysilane and phenyldimethyloctyloxysilane products, the two compounds had to be synthesized, as they were not commercially available. The synthetic procedures are detailed in the Experimental Section. In general, the appropriate chlorosilane was refluxed with 1-octanol in THF in the presence of triethylamine (Scheme 2). The products were subsequently purified by vacuum distillation, characterized and used as standard references in the gas-chromatography analyses.

Scheme 2. Chemical synthesis of the octyl-silylethers.<smiles>[R][Si]([R])([R])Cl</smiles>

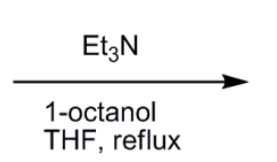<smiles>[R][Si]([R])([R])OCCCCCCCC</smiles>

$\mathrm{R}_{1}=$ methyl or phenyl

octyl-silyl ether

As shown in Figure 1 and detailed in Tables 1 and 2, selected enzymes such as trypsin, Rhizopus oryzae lipase (ROL) and lysozyme were able to catalyze the formation of the octyltrimethyl-silyl ether (Figure 1, left) and/or the octylphenyldimethylsilyl ether (Figure 1, right) after $24 \mathrm{~h}$ at room temperature. In similar conditions, no condensation was observed in the negative control reactions nor in the presence of all the other enzymes tested in the $\mathrm{Si}-\mathrm{O}$ bond formation screening [9].

Figure 1. Enzyme-catalyzed transetherification and/or silanol alcohol condensation/exchange study between trimethylethoxysilane (left) or phenyldimethylethoxysilane (right) with 1-octanol (filled bars) or tert-butanol (bars with patterns), after $24 \mathrm{~h}$ at $25^{\circ} \mathrm{C}$.
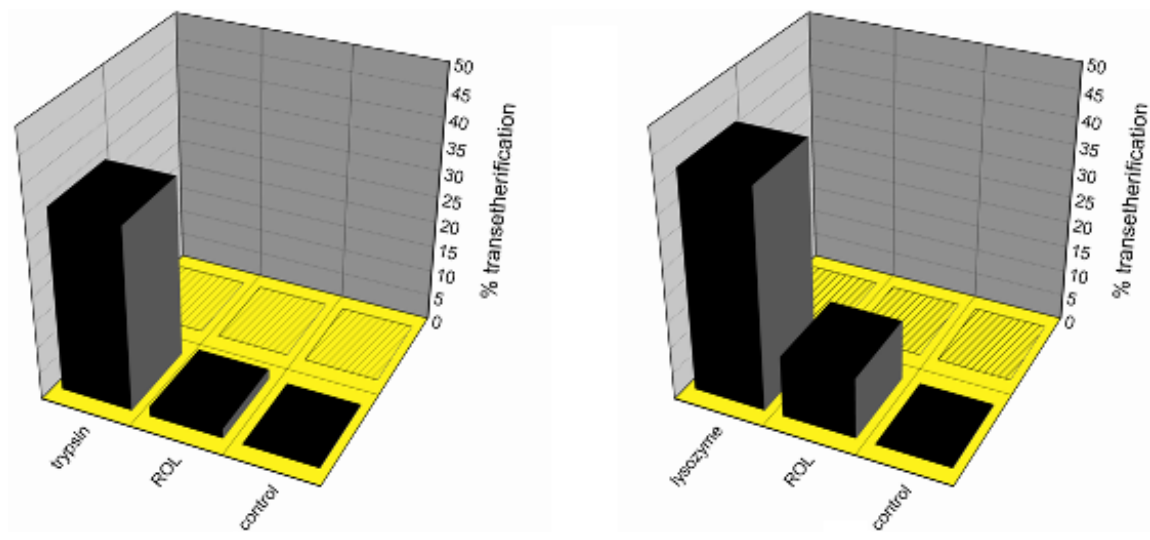
Table 1. Enzyme-catalyzed transetherification reactions between trimethylethoxysilane and 1-octanol or tert-butanol after $24 \mathrm{~h}$ at $25{ }^{\circ} \mathrm{C}$.

\begin{tabular}{|c|c|c|c|c|}
\hline \multirow[b]{2}{*}{ Reaction } & \multicolumn{3}{|c|}{ \% Yield (Normalized) } & \multirow[b]{2}{*}{$\mathrm{Me}_{3} \mathrm{SiOR}^{4}$} \\
\hline & $\mathrm{Me}_{3} \mathrm{SiOEt}^{1}$ & $\mathrm{Me}_{3} \mathrm{SiOH}^{2}$ & HMDS $^{3}$ & \\
\hline negative control, 1-octanol & 91.3 & 5.3 & 3.4 & 0.0 \\
\hline negative control, $5 \%$ water in tert-butanol & 34.7 & 64.4 & 1.0 & 0.0 \\
\hline Rhizopus oryzae lipase, 1-octanol & 81.8 & 13.0 & 3.4 & 1.8 \\
\hline Rhizopus oryzae lipase, $5 \%$ water in tert-butanol & 77.0 & 23.0 & 0.0 & 0.0 \\
\hline bovine pancreatic trypsin, 1-octanol & 7.0 & 52.9 & 2.3 & 34.9 \\
\hline bovine pancreatic trypsin, $5 \%$ water in tert-butanol & 3.8 & 92.1 & 4.1 & 0.0 \\
\hline
\end{tabular}

Table 2. Enzyme-catalyzed transetherification reactions between phenyldimethyethoxysilane and 1-octanol or tert-butanol after $24 \mathrm{~h}$ at $25^{\circ} \mathrm{C}$.

\begin{tabular}{|c|c|c|c|c|}
\hline \multirow[b]{2}{*}{ Reaction } & \multicolumn{4}{|c|}{$\%$ Yield $^{1}$} \\
\hline & $\mathrm{PhMe}_{2} \mathrm{SiOEt}^{2}$ & $\mathrm{PhMe}_{2} \mathrm{SiOH}^{3}$ & $\left(\mathrm{PhMe}_{2} \mathrm{OSi}\right)_{2}-\mathrm{O}^{4}$ & $\mathrm{PhMe}_{2} \mathrm{SiOR}^{5}$ \\
\hline negative control, 1-octanol & 100.0 & 0.0 & 0.0 & 0.0 \\
\hline negative control, $5 \%$ water in tert-butanol & 88.8 & 11.2 & 0.0 & 0.0 \\
\hline Rhizopus oryzae lipase, 1-octanol & 66.8 & 21.5 & 0.0 & 11.7 \\
\hline $\begin{array}{l}\text { Rhizopus oryzae lipase, } 5 \% \text { water } \\
\text { in tert-butanol }\end{array}$ & 95.8 & 4.2 & 0.0 & 0.0 \\
\hline chicken egg white lysozyme, 1-octanol & 3.2 & 55.0 & 0.0 & 41.8 \\
\hline $\begin{array}{l}\text { chicken egg white lysozyme, } 5 \% \text { water } \\
\text { in tert-butanol }\end{array}$ & 71.5 & 28.5 & 0.0 & 0.0 \\
\hline
\end{tabular}

Figure 1 shows percentage yield of octyl-ether formation based on the quantitative chromatographic data, the mass balance being completed by either unreacted alkoxysilane, silanol formed by simple hydrolysis, or the corresponding disiloxane from the condensation product with another molecule of silanol (see Scheme 1). Notably, in the absence of any biocatalyst (negative control), no octyl-silyl ether was observed, denoting the critical role of the enzyme in the alkoxysilane transetherification transformation.

To our knowledge, this is the first case of an enzyme-mediated transetherification reaction of organo-silicon substrate under mild conditions. It is apparent that there is advantage in using an enzyme at room temperature over the conventional synthetic procedure the synthesis of the octyl-silyl products by avoiding the use of harsh chemicals and elevated reaction temperature.

Interestingly, the enzymatic screening conducted during the hydrolysis and condensation study of monoalkoxysilanes in wet tert-butanol (see [9], Figure 1 and Tables 1 and 2) did not lead to any tert-butylsilyl ether product formation. This may be due to the steric hindrance of tert-butyl groups, as opposed to the longer but more flexible octyl chains, which may be more accessible to the enzyme cavities. Rhizopus oryzae lipase (ROL) is a small globular protein of approximately $32 \mathrm{kDa}$ that exists 
as a monomer in solution. This enzyme catalyzes the hydrolysis of triglycerides to yield the free fatty acid. It hydrolyzes triglycerides with alkyl chains in the region of 8 to 18 carbons long, whereas poor activity was observed with short-chain fatty esters. Notably, ROL was observed to catalyze the formation of both trimethyloctyloxysilane and phenyldimethyloctyloxysilane. Conversely, the lipase was not able to catalyze the formation of tert-butyl silyl ethers. This is in agreement with the natural substrate-selectivity of the ROL, and suggests the involvement of the active site during the catalysis. Trypsin, a serine-protease that cleaves peptide chains mainly at the carboxyl side of the amino acids lysine or arginine, was a good biocatalyst for trimethyloctyl silyl ether formation, and this is in line with our previous studies on the alkoxysilane hydrolysis and condensation reactions [7,9]. Lysozyme is a small $(14.3 \mathrm{kDa})$ but robust protein consisting of a single 129 amino acid polypeptide chain , and it was already observed to be a good siloxane-bond biocatalyst [8]. This enzyme produced the highest yield of the phenyldimethyloctyl-silyl ether in this study. The reason for the unusual selectivity of this glycoside hydrolase is not yet understood and will be the subject of further investigations. The work proves the potential of the use of (bio)-macromolecules as catalytic aids on unusual substrates under facile and mild reaction conditions and justifies further exploration for biotransformation in silicon chemistry.

\section{Experimental Section}

\subsection{Materials}

Trimethylsilanol $\left(\mathrm{Me}_{3} \mathrm{SiOH}\right)$ was obtained from the Dow Corning Corporation (Midland, MI, USA). Enzymes and all the other chemicals were purchased from Sigma-Aldrich (Poole, UK). All the materials were used as received without further modification. Ultra high purity water (UHP) was obtained from a f Milli-Q system at The Open University (Milton Keynes, UK).

\subsubsection{Synthesis of Trimethyloctyloxysilane}

1-Octanol (31.25 g, $0.24 \mathrm{M})$ and triethylamine $(24.28 \mathrm{~g}, 0.24 \mathrm{M})$ were dissolved in anhydrous THF (300 $\mathrm{mL})$ under nitrogen in a 3-necked round-bottomed flask, and a solution of chlorotrimethylsilane $(15.21 \mathrm{~g}, 0.14 \mathrm{M})$ in anhydrous THF $(100 \mathrm{~mL})$ was added dropwise to the mixture over one hour. After gently refluxing at approximately $70{ }^{\circ} \mathrm{C}$, a white solid precipitated (triethylammonium chloride). The solid was filtered off and the filtrate recovered. The solvent and excess triethylamine were removed using a rotary evaporator, and the transparent liquid purified by distillation at $120{ }^{\circ} \mathrm{C}$ and approximately 85 mbar. The product was characterized by NMR spectroscopy and GC-MS, and it was used as a GC-standard in order to understand the product distribution during the enzyme-catalyzed transetherification studies. Yield $67 \% .{ }^{1} \mathrm{H} \mathrm{NMR}\left(\mathrm{CDCl}_{3}\right.$, $300 \mathrm{MHz}): \delta 3.45\left(t, 2 \mathrm{H}, J 7.4, \mathrm{O}-\mathrm{CH}_{2}\right), 1.41\left(\mathrm{~m}, 2 \mathrm{H}, \mathrm{OCH}_{2}-\mathrm{CH}_{2}\right), 1.16\left(\mathrm{~m}, 10 \mathrm{H}, \mathrm{OCH}_{2} \mathrm{CH}_{2}-\left(\mathrm{CH}_{2}\right)_{5}\right)$, $0.77\left(3 \mathrm{H}, t, J 7.4, \mathrm{O}\left(\mathrm{CH}_{2}\right)_{7}-\mathrm{CH}_{3}\right)$ and $0.0\left(s, 9 \mathrm{H}, \mathrm{Si}\left(\mathrm{CH}_{3}\right)_{3}\right)$ ppm. ${ }^{13} \mathrm{C} \mathrm{NMR}\left(\mathrm{CDCl}_{3}, 75.45 \mathrm{MHz}\right)$

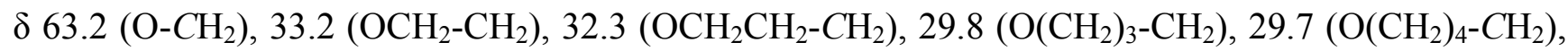
$26.3\left(\mathrm{O}\left(\mathrm{CH}_{2}\right)_{5}-\mathrm{CH}_{2}\right), 23.1\left(\mathrm{O}\left(\mathrm{CH}_{2}\right)_{6}-\mathrm{CH}_{2}\right), 14.5\left(\mathrm{O}\left(\mathrm{CH}_{2}\right)_{7}-\mathrm{CH}_{3}\right)$ and $0.0\left(\mathrm{Si}-\left(\mathrm{CH}_{3}\right)_{3}\right) .{ }^{29} \mathrm{Si} \mathrm{NMR}$ $\left(\mathrm{CDCl}_{3}, 79.3 \mathrm{MHz}\right): \delta 17.5 \mathrm{ppm}$. Mass $m / z$ (EI) $202\left(\mathrm{M}^{+}\right), 187\left(\mathrm{M}^{+}-\mathrm{CH}_{3}\right)$. NMR data were consistent with those reported [10]. 


\subsubsection{Synthesis of Phenyldimethyloctyloxysilane}

1-Octanol $(28.65 \mathrm{~g}, 0.22 \mathrm{M})$ and triethylamine $(22.26 \mathrm{~g}, 0.22 \mathrm{M})$ were dissolved in anhydrous THF (250 mL) under nitrogen in a 3-necked round-bottomed flask and a solution of chlorodimethylphenylsilane $(20.48 \mathrm{~g}, 0.12 \mathrm{mM})$ in anhydrous THF $(100 \mathrm{~mL})$ added dropwise to the mixture over one hour. After gently refluxing at approximately $70{ }^{\circ} \mathrm{C}$ for $2 \mathrm{~h}$, the triethylammonium chloride was filtered off and the filtrate collected. After removing the solvent and excess of triethylamine using a rotary evaporator, the product was purified by distillation at $142{ }^{\circ} \mathrm{C}$ and approximately 85 mbar. The product was characterized by NMR spectroscopy and GC-MS and it was used as a GC-standard in order to understand the product distribution during the enzyme-catalyzed transetherification studies. Yield 44\%. ${ }^{1} \mathrm{H} \mathrm{NMR}\left(\mathrm{CDCl}_{3}, 300 \mathrm{MHz}\right): \delta$ 7.22-7.02-7.01 $(m, 5 \mathrm{H}$, aromatic $\mathrm{H}), 3.26\left(t, 2 \mathrm{H}, J\right.$ 6.6, O- $\left.\mathrm{CH}_{2}\right), 1.17\left(\mathrm{~m}, 2 \mathrm{H}, \mathrm{OCH}_{2}-\mathrm{CH}_{2}\right), 0.90\left(\mathrm{~m}, 10 \mathrm{H}, \mathrm{OCH}_{2} \mathrm{CH}_{2}-\left(\mathrm{CH}_{2}\right)_{5}\right)$, $0.51\left(t, 3 \mathrm{H}, J 3.0, \mathrm{O}\left(\mathrm{CH}_{2}\right)_{7}-\mathrm{CH}_{3}\right)$ and $0.0\left(s, 6 \mathrm{H}, \mathrm{Si}\left(\mathrm{CH}_{3}\right)_{2}\right) \mathrm{ppm} .{ }^{13} \mathrm{C} \mathrm{NMR}\left(\mathrm{CDCl}_{3}, 75.45 \mathrm{MHz}\right)$ :

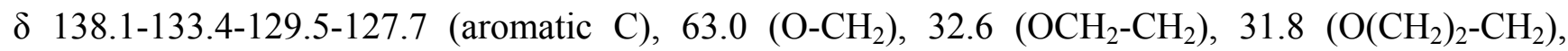

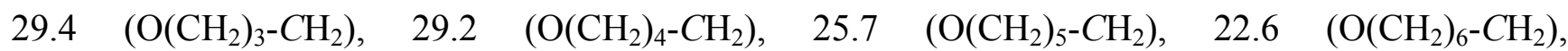
$14.0\left(\mathrm{O}\left(\mathrm{CH}_{2}\right)_{7}-\mathrm{CH}_{3}\right)$ and $-1.7\left(\mathrm{Si}-\left(\mathrm{CH}_{3}\right)_{3}\right) .{ }^{29} \mathrm{Si} \mathrm{NMR}\left(\mathrm{CDCl}_{3}, 79.3 \mathrm{MHz}\right): \delta 7.5 \mathrm{ppm}$. Mass $\mathrm{m} / z(\mathrm{EI})$ $264\left(\mathrm{M}^{+}\right), 249\left(\mathrm{M}^{+}-\mathrm{CH}_{3}\right)$. NMR data were consistent with those reported [11].

\subsection{Enzyme-Catalyzed Transetherification Reactions}

The reactions were formulated with a 5:1 alkoxysilane $(100 \mathrm{mg})$ to enzyme $(20 \mathrm{mg})$ weight ratio in $0.5 \mathrm{~g}$ of alcohol (water-equilibrated 1-octanol or tert-butanol containing $5 \%(v / v)$ buffered water). Prior to analysis, the reactions were filtered through a Whatman Autovial ${ }^{\circledR} 50.45-\mu \mathrm{m}$ Teflon ${ }^{\circledR}$ filter (Fisher Scientific Ltd., Loughborough, UK). The closed (screw capped) two-phase reactions were conducted in inert glass vials at $25{ }^{\circ} \mathrm{C}$ with magnetic stirring for $24 \mathrm{~h}$. The reaction products were isolated and analyzed by GC-FID (quantitative, Agilent, Wokingham, UK) and GC-MS (qualitative, Agilent, Wokingham, UK).

Control reactions are defined as non-enzymatic reactions. Specifically, experiments conducted in the absence of a protein are defined as negative control reactions.

\subsection{Gas Chromatography-Flame Ionization Detection}

The gas chromatography (GC) analyses were performed with an Agilent 6890 Series injector on an Agilent 6890 plus gas chromatograph (GC) with a flame-ionization detector (FID).

The system was configured as detailed in Table 3. Dodecane was used as an internal standard to gravimetrically quantitate the chromatographic analyses. The samples were prepared at $\sim 1 \%(w / w)$ product in a THF solution containing $1 \%(w / w)$ dodecane. Based on triplicate measurements, the response factors for the analytes were calculated, Equation (1), and found to be linear as a function of concentration over four orders of magnitude (i.e., $0.01 \%-10 \%(w / w)$ (Table 4):

$$
\mathrm{RF}_{\text {analyte }}=\left([\text { analyte }] / \text { Area }_{\text {analyte }}\right) \times\left(\text { Area }_{I S} /[\text { IS }]\right) \times \mathrm{RF}_{\text {IS }}
$$

where $\mathrm{RF}_{\text {analyte }}=$ response factor for the analyte, $[$ analyte $]=$ concentration of the analyte, Area $a_{\text {analyte }}=$ peak area of the analyte, Area $_{\mathrm{IS}}=$ peak area of the internal standard, [IS] = concentration of the internal 
standard, $\mathrm{RF}_{\mathrm{IS}}=$ response factor for the internal standard $=1$. Equation (1) was then solved to quantitatively calculate the concentration of an analyte in the presence of an internal standard, Equation (2):

$$
[\text { analyte }]=\left(\mathrm{Rf}_{\text {analyte }} \times \text { Area }_{\text {analyte }}\right) \times\left([\mathrm{IS}] / \text { Area }_{I S}\right)
$$

Table 3. GC-FID experimental parameters.

\begin{tabular}{ll}
\hline Parameter & Setting \\
\hline Carrier gas & $99.9995 \%$ Ultra high purity helium $(\mathrm{UHP})$ \\
GC inlet, split & $250{ }^{\circ} \mathrm{C}$, split ratio $=100: 1$, constant flow (rate $\left.=1.0 \mathrm{~mL} / \mathrm{min}\right)$ \\
Detector & Flame ionization detector at $275^{\circ} \mathrm{C}, \mathrm{H}_{2}=40 \mathrm{~mL} / \mathrm{min}, \mathrm{Make}$ up $\mathrm{N}_{2}=45 \mathrm{~mL} / \mathrm{min}$ \\
GC column & $\mathrm{HP}-5 \mathrm{MS}$ crosslinked $5 \%$ phenylmethylsiloxane film $(30 \mathrm{~m} \times 0.25 \mathrm{~mm}, 0.25 \mu \mathrm{m}$ film) \\
GC temperature program & $50(2) \rightarrow 250(8)$ at $10^{\circ} \mathrm{C} / \mathrm{min}, 30$ min total run time \\
Internal standard & $\sim 1 \%(\mathrm{w} / \mathrm{w})$ dodecane in THF \\
Data system & Agilent Technologies ChemStation \\
\hline
\end{tabular}

Table 4. GC-FID analyte retention times and response factors.

\begin{tabular}{|c|c|c|c|c|}
\hline \multirow[b]{2}{*}{ Analyte $^{1}$} & \multicolumn{4}{|c|}{ Response Factor (RF) } \\
\hline & Retention Time (min) & Average & Standard Deviation & RSD $^{2}$ \\
\hline $\mathrm{Me}_{3} \mathrm{SiOEt}$ & 2.75 & 2.00 & 0.007 & $3.3 \%$ \\
\hline $\mathrm{Me}_{3} \mathrm{SiOH}$ & 2.63 & 2.35 & 0.091 & $3.9 \%$ \\
\hline HMDS & 3.22 & 2.01 & 0.052 & $2.6 \%$ \\
\hline $\mathrm{PhMe}_{2} \mathrm{SiOEt}$ & 10.37 & 1.35 & 0.007 & $0.5 \%$ \\
\hline $\mathrm{PhMe}_{2} \mathrm{SiOH}$ & 9.92 & ND & ND & ND \\
\hline Phenyl disiloxane & 17.42 & ND & ND & ND \\
\hline $\mathrm{PhMe}_{2} \mathrm{SiO}\left(\mathrm{CH}_{2}\right)_{7} \mathrm{CH}_{3}$ & 17.48 & 2.02 & 0.038 & $0.2 \%$ \\
\hline $\mathrm{Me}_{3} \mathrm{SiO}\left(\mathrm{CH}_{2}\right)_{7} \mathrm{CH}_{3}$ & 10.97 & 2.15 & 0.027 & $1.3 \%$ \\
\hline Dodecane & 11.11 & 1.00 & & \\
\hline
\end{tabular}

\subsection{Gas Chromatography-Mass Spectrometry}

The gas chromatography-mass spectrometry (GC-MS) analyses were performed with an Agilent 6890 Series injector on an Agilent 6890 plus gas chromatograph with a 5973 MS detector. The MS detector was autotuned with perfluorotributylamine (PFTBA) prior to analysis. The system was configured as detailed in Table 5. 
Table 5. GC-MS Experimental Parameters.

\begin{tabular}{ll}
\hline Parameter & Setting \\
\hline Carrier gas & $99.999 \%$ high purity helium \\
GC inlet, split & $250{ }^{\circ} \mathrm{C}$, split ratio $=50: 1$, constant flow (rate $=1.0 \mathrm{~mL} / \mathrm{min}$.) \\
GC column & $\mathrm{HP}-5 \mathrm{MS}$ crosslinked $5 \%$ phenyl methylsiloxane film \\
& $(30 \mathrm{~m} \times 0.25 \mathrm{~mm}, 0.25 \mu \mathrm{m}$ film) \\
GC temperature program & $50(2) \rightarrow 250(8)$ at $10^{\circ} \mathrm{C} / \mathrm{min}, 30$ min total run time \\
GC-MS transfer line temperature & $350^{\circ} \mathrm{C}$ \\
MS ionization & electron impact \\
MS full scanning mass range & $15-500$ amu, 1 scan $/ \mathrm{s}$ \\
Data system & Agilent Technologies ChemStation \\
\hline
\end{tabular}

\subsection{NMR Spectroscopy}

NMR spectra were obtained using a JEOL ECX 400 NMR spectrometer (Jeol, Watchmead, UK) fitted with multinuclear probes. ${ }^{13} \mathrm{C}$ spectra were broad-band decoupled. The pulse delay for ${ }^{29} \mathrm{Si}$ spectra was standardized at $15 \mathrm{~s}$. All spectra were recorded at room temperature $\left(20{ }^{\circ} \mathrm{C}\right)$ using deuterated solvents. The internal NMR reference compound was TMS in all ${ }^{1} \mathrm{H},{ }^{13} \mathrm{C}$ and ${ }^{29} \mathrm{Si} \mathrm{NMR}$ spectra, unless it interfered with the product peaks; where this was the case, the residual solvent peak was used as standard.

\section{Conclusions}

The use of wet 1-octanol as a solvent system for the enzyme-catalyzed hydrolysis and condensation of alkoxysilanes led to the observation that some enzymatic candidates promoted the transetherification and/or alcohol exchange of alkoxysilanes. To our knowledge, this is the first example of a biocatalyzed process leading to the synthesis of a new alkoxysilane. The route offers a clear example for further expanding the potential of bio-catalyzed reactions at a silicon centre and would offer several advantages with respect to conventional chemical procedures, such as benign reaction conditions and the use of non-toxic catalysts. Further studies with different alcohols and in the absence of water are planned to explore the full potential of this novel biomimetic transetherification.

\section{Acknowledgments}

We gratefully acknowledge generous financial and technical support from Dow Corning Corporation, MI, USA.

\section{Conflict of Interest}

The authors declare no conflict of interest.

\section{References}

1. Kawamoto, T.; Tanaka, A. In Enzymes in Nonaqueous Solvents: Methods and Protocols; Vulfson, E.N., Halling, P.J., Holland, H.L., Eds.; Humana Press Inc.: Totowa, NJ, USA, 2001. 
2. Nishino, H.; Mori, T.; Okahata, Y. Enzymatic silicone oligomerization catalyzed by a lipid-coated lipase. Chem. Commun. (Camb.) 2002, 22, 2684-2685.

3. Fattakhova, A.N.; Chirko, E.P.; Ofitserov, E.N. Fermentative hydrolysis of the silicon-oxygen bond. Biol. Nauki 1992, 4, 100-105.

4. Cha, J.N.; Shimizu, K.; Zhou, Y.; Christiansen, S.C.; Chmelka, B.F.; Stucky, G.D.; Morse, D.E. Silicatein filaments and subunits from a marine sponge direct the polymerization of silica and silicones in vitro. Proc. Natl. Acad. Sci. USA 1999, 96, 361-365.

5. Kroger, N.; Deutzmann, R.; Sumper, M. Polycationic peptides from diatom biosilica that direct silica nanosphere formation. Science 1999, 1129-1131.

6. Bassindale, A.; Taylor, P.G.; Abbate, V.; Brandstadt, K.F. Simple and mild preparation of silica-enzyme composites from silicic acid solution. J. Mater. Chem. 2009, 19, 7606-7609.

7. Bassindale, A.R.; Brandstadt, K.F.; Lane, T.H.; Taylor, P.G. Enzyme-catalysed siloxane bond formation. J. Inorg. Biochem. 2003, 96, 401-406.

8. Abbate, V.; Bassindale, A.R.; Brandstadt, K.F.; Lawson, R.; Taylor, P.G. Enzyme mediated silicon-oxygen bond formation; the use of Rhizopus oryzae lipase, lysozyme and phytase under mild conditions. Dalton Trans. 2010, 39, 9361-9368.

9. Abbate, V.; Bassindale, A.R.; Brandstadt, K.F.; Taylor, P.G. A large scale enzyme screen in the search for new methods of silicon-oxygen bond formation. J. Inorg. Biochem. 2011, 105, $268-275$.

10. Tietze, L.F.; Boege, K.; Vill, V. Liquid-crystalline D-glucose dialkyl acetals and dodecyl D-glucofuranosides. Chem. Ber. 1994, 127, 1065-1068.

11. Matsumoto, A.; Ito, Y. New generation of organosilyl radicals by photochemically induced homolytic cleavage of silicon-boron bonds. J. Org. Chem. 2000, 65, 5707-5711.

(C) 2013 by the authors; licensee MDPI, Basel, Switzerland. This article is an open access article distributed under the terms and conditions of the Creative Commons Attribution license (http://creativecommons.org/licenses/by/3.0/). 